\title{
血友病と加齢疾患
}

長尾 梓*

\section{Clinical concerns in the ageing hemophilia patient}

\author{
Azusa NAGAO
}

要約：近年, 血友病患者の生活の質は劇的に向上し, 平均余命は高くなりつつあるが, その反面高血圧や心血 管疾患・血栓性疾患などの加齢に関連する合併症の報告が増加し，いくつかの前向き研究も進行中である. 重 症血友病における虚血性疾患の発症率は, その凝固能の低下ゆえに一般集団よりも低いとする報告がほとんど だが, 非重症血友病の罹患率は一般集団と同じであると報告されており, 定期補充療法が浸透し, 非凝固因子 製剤も広く使われるようになった今後は, 重症血友病患者においてもその発症率が上昇する可能性が考えられ る. 虚血性疾患を合併した血友病患者の「止血」と「抗血栓」のバランスをどう取るかは非常にChallenging な テーマであり, 今後ガイドラインの作成が望まれる分野でもある. 本総説では, その他悪性腫瘍, インヒビ ター, 骨密度低下も含め日本人成人血友病患者の現状と, 現時点で最新の問題点とその状況について概説する.

Key words: ageing, cardiovascular diseases, haemophilia, comorbidities

\section{1. 概論}

近年，血友病において定期補充療法の効果が実証 され，小児のみならず成人においても高い定期補充 率が報告されている ${ }^{1,2)}$. また, 半減期延長製剤や非 凝固因子製剂など様々な治療オプションも利用可能 になった ${ }^{3)}$. 一方, 薬害によるヒト免疫不全ウイル ス (human immunodeficiency virus: HIV) 感染は, 抗 HIV 薬療法の進歩によってコントロール可能な慢性 疾患となり, $\mathrm{C}$ 型肝炎 (hepatitis $\mathrm{C}$ virus: $\mathrm{HCV}$ ) も 2015 年に発売された直接作用型抗ウイルス剂によっ て高いウイルス消失率が得られることから, 肝硬変 および肝細胞癌（hepatocellular carcinoma: HCC）に よる死亡率の低下が大いに期待されている ${ }^{4)}$.この ような状況下で血友病患者の生活の質は劇的に向上 し, 平均余命は高くなりつつあるが, その反面加齢 疾患を合併する患者の増加が懸念されている.

*責任者連絡先：

荻窪病院血液凝固科

干 167-0042 東京都杉並区今川 3-1-25

Tel: 03-3399-1101, Fax: 03-3399-1107

E-mail: azusa_nagao@ogikubo-hospital.or.jp
近年, 世界的に血友病における高血圧や心血管疾 患・血栓性疾患などの加齢に関連する合併症の報告 が増加し, いくつかの前向き研究も進行中である. そのなかでもヨーロッパの研究グループである ADVANCEグループは多岐にわたる前向き研究を精 力的に進めている ${ }^{5)}$.

重症血友病における虚血性疾患の発症率は, その 凝固能の低下ゆえに一般集団よりも低いとする報告 が各国から多数ある。しかし, 非重症血友病の罹患 率は，一般集団と同じであると報告されており，定 期補充療法が浸透し, 非凝固因子製剂も広く使われ るようになった今後は, 重症血友病患者においても その発症率が上昇する可能性が考えられる。虚血性 疾患を合併した血友病患者の「止血」と「抗血栓」 のバランスをどう取るかは非常に Challenging なテー マであり, 今後ガイドラインの作成が望まれるが, そのためにはエビデンスレベルの高い研究が必要で ある、筆者はヨーロッパの ADVANCE グループに倣 う形で, 本邦の主要な成人血友病診療施設と共同し, 40 歳以上の血友病患者の前向き研究 (ADVANCE JAPAN）を実施中である ${ }^{6)}$. 本総説では, ADVANCE JAPAN の前段研究でもある日本人成人血友病 711 人 
表 1 本邦抒よび他国からの虚血性疾患の発生に関する報告のまとめ

\begin{tabular}{lcccc}
\hline & 研究対象年齢 & 重症血友病 & 非重症血友病 & ALL \\
\hline 日本人 ${ }^{7)}$ & 30 歳以上 & $2 / 458(0.4 \%)$ & $0 / 251(0 \%)$ & $2 / 711(0.3 \%)$ \\
カナダ 9$)$ & 35 歳以上 & $1 / 48(2 \%)$ & $17 / 174(9.8 \%)$ & \\
ヨーロッパ 8) & 30 歳以上 & $17 / 344(5 \%)$ & $36 / 365(10 \%)$ & \\
台湾 ${ }^{10)}$ & 全員 & & & \\
スウェーデン ${ }^{29)}$ & 30 歳以上 & & & $52 / 1,054(5 \%)$ \\
US $^{30)}$ & 54 歳以上 & & & $302 / 1,431(14 \%)$ \\
\hline
\end{tabular}

のデータを収集した観察研究 ${ }^{7)}$ の結果から, 日本人 成人血友病患者の現状と, 現時点で最新の血友病成 人患者における問題点とその状況について概説する.

\section{2. 虚血性疾患}

\section{1）発生率}

我々の観察研究で得られた最も驚くべき結果は, 日本人血友病患者に扔ける非常に低い虚血性疾患の 既往歴（2016年時点で $0.3 \%$ ）であった。この結果 は, アジア圈の台湾を含む他の国から報告されたも のよりもさらに低かった（表1)。オランダおよび英 国で行われた多施設共同観察研究（デー夕収集期間 2009 年から 2011 年) では 709 人の患者において, 心 血管疾患の累積発生率が重症血友病 6.9\%あり, 非重 症血友病で $12 \%$ であった ${ }^{8)}$. カナダの 5 センターか らの報告（デー夕収集期間 2000～2011 年）では，血 友病 294 人における虚血性疾患の発生率は重症で $2 \%$, 非重症で $9.8 \%$ であった ${ }^{9)}$. 台湾の国民健康保 険データベースに基づいて行われた研究（デー夕収 集期間 1998 年から 2010 年）では，すべての年齢層 における心血管イベントの累積発生率は 1,054 人中 12 件であり，一般集団のそれと有意な差がないこと が明らかになった ${ }^{10)}$. ちなみに台湾では肥満が問題 になっており，同じアジア圈でも有意に瘦せの多い 日本人血友病とは異なる状況が報告されている。 そ の他，スウェーデン，米国の報告を合わせて表 1 に 示した。これらの報告と直接比較することは難しい が, 日本人成人血友病患者における虚血性疾患の $0.3 \% の$ 有病率は極端に低い。その原因は不明だが, 日本人の遺伝的要素, 食生活・生活習慣を含む一般
的な生活様式の要素などが関連していると考える. 日本人一般男性の虚血性疾患発生頻度は, 保険デー タベースから約 20,000 人の男性を 8 年間追跡した研 究において, 40〜 55 歳の年齢層で 1.79\%であり, 血 友病症例では明らかに低いことがうかがえる ${ }^{10)}$. 以 上より，日本の血友病患者に抢ける虚血性疾患の有 病率は顕著に低いと考えられるが，今後は増加する 可能性もあり ADVANCE Japan での情報収集を継続 したい.

\section{2) 死亡率}

発生率自体が低いため死亡率を調査した報告は少 ない. 死亡率が低くなる可能性として，1. 生活習慣 病などのリスクファクターの有病率が低い，2．動脈 硬化（頸動脈肥厚と冠動脈石灰化）は一般男性と同 等であるが，プラーク破裂時の血栓形成能が低い， などの可能性が報告されている ${ }^{11)}$ 。実際, 我々の研 究でも血友病患者の脂質異常症有病率や喫煙率は一 般男性より少ない。 また，プラーク周辺では凝固能 立進と PAR-2 などを介した炎症が互いに相互作用 し，XaはPAR-2 を活性化する作用があるため，Xa 生成能の低い血友病に㧍いてはプラーク破裂時の血 栓形成能が低い可能性を示唆する報告もある ${ }^{12)}$.

\section{3）発症時の治療}

虚血性疾患発症時に経皮的冠動脈インターベン ション（percutaneous coronary intervention: PCI）を実 施する場合には，いくつかの選択肢があるが，特に 血友病症例においては, 動脈アクセスルートは日本 循環器学会 /日本心臓血管外科学会合同ガイドライ ン「安定冠動脈疾患の血行再建ガイドライン（2018 年改訂版)」の推奨する経橈骨動脈アプローチの方 が，大腿動脈アプローチよりも出血リスクが低下す 
ると考えられる。ただし，透析中であったり，動脈 が細い場合, 経橈骨動脈アプローチに経験豊富でな い術者の場合には実施できない可能性もある.PCI 時に使用するステントは, 非血友病症例には標準的 に用いられている薬剂流出性ステント (drug eluting stent: DES) ではなく, 抗血小板薬 2 剂併用療法 (dual anti-platelet therapy: DAPT）の期間が短いベアメタル ステント（bare metal stent: BMS）を使うべきとされ, Boehnel らによるシステマティックレビューにおい ても（2016年までに発表された論文を含む）BMS31 人, DES2 人と圧倒的に BMS が多く使われている ${ }^{13)}$. しかし，新世代 DES では DAPT の期間が，これまで の 6〜12 ケ月から最低 1ヶ月へと大幅に短縮されて いることから, BMS ではなく DES を選択すべきで あるという総説が 2020 年 Haemophilia 誌に発表さ れた ${ }^{14)}$.「安定冠動脈疾患の血行再建ガイドライン (2018 年改訂版)」においても, 手術などによる DAPT の中止が必要な場合，あるいは出血リスクが高い患 者に対して, DAPT期間を 1 ケ月に短縮しても, 新 世代の DES を上回るメリットが BMS には 1 つな かったことがRCTで示されており，2018年の ESC/ EACTS のガイドラインでも, すべての状況で新世代 DESが推奨されている，と強く述べられている.さ らには, BMS は日本では流通がまれであることから 院内在庫を置く病院は少ないと推察する. 以上より, 血友病症例の PCI 実施には, これまでよりも綿密な 循環器内科との相談が必要で, できるだけ DAPT 期 間を短くし出血リスクを軽減したいと思う我々の思 いと, 再狭窄を避けたい循環器内科との擦り合わせ を要する。なお, 教科書的には冠動脈バイパス手術 が選択される左冠動脈主管部や 3 枝病変でも状況に よってはPCIが行われる場合があるが，その場合は DAPT は長期間に及んでしまうため, ケース毎にべ ス卜な選択ができるよう循環期内科, 心臓血管外科 と相談されたい.PCI 中の凝固因子製剤の補充量に ついてのエビデンスはないが, PCI 中は通常へパリ ンが併用されるため, 大手術に準じて十分量を投与 する必要があると思われる。 DAPT あるいは抗血小 板薬一剂療法（single anti-platelet therapy: SAPT）期 間中の凝固因子の至適トラフ值についても, エビデ ンスはまだないが, ADVANCEグループのデルファ
イ法による検討などでは，DAPT 期間はトラフ $15 \%$ 以上, SAPT 期間中は 1〜 5\%に保つことが推奨され ている ${ }^{15)}$.

\section{3. 高血圧}

2010 年代前半, 血友病の高血圧罹患率についての 論文が多数発表され, その多くが血友病は一般集団 より高血圧の有病率が高いと報告している ${ }^{16)}$. 原因 は不明であるが, 初期の論文で腎蔵における微小出 血が原因ではないかと考察されていたことから，そ れに習う論文がほとんどであった. ADVANCE group は H3 studyの中で顕微鏡的血尿と高血圧の関係を調 查し ${ }^{16,17)} ， 2016$ 年に「顕微鏡的血尿」と「高血圧」 は相関しないとい報告したものの,「高血圧」且つ 「家族歴のある」血友病患者について再解析した場合 には, 有意な顕微鏡的血尿があり, その回数が多い ほど, 高血圧の有病率が上昇することが確認された (図 1). したがって, 顕微鏡的血尿は血友病患者の 高血圧傾向の原因の一つである可能性が示唆される. 一方, 我々の研究では $130 / 85 \mathrm{mmHg}$ 以上を高血圧と 定義した場合，一般男性（国民健康栄養調査から引 用）よりも優位に高血圧の有病率が低いという, 他 国とは全く異なる結果が得られた（表 2)。2017年の スイスからの報告は, 70 歳以上の血友病患者は一般 男性より高血圧が少ないとしているが ${ }^{18)}$, 我々はコ ホートが異なること, 血友病群と一般男性群の血圧 測定方法が異なる (血友病群; 外来で測定され安静 時とは限らない, 一般男性; 一定の安静期間後に 2 度測定されている）などのリミテーションがあるた め, 今後の前向き研究で明らかにしたい. その他我々 の研究では, 高血圧がある日本人血友病患者は一般 集団と同様, 多変量解析で, 年齢, BMI, 慢性腎臓 病, およびHIV 感染とインヒビターとの関連が認め られた（表3). HIV 感染が高血圧の誘因となること は既に知られているが, インヒビターは血友病に特 異的であり，オッズ比は 7.529 と非常に高かった。 インヒビター症例は出血傾向が強いため, 前述の腎 臓での微小出血と関連がある可能性がある。 その他, 関節障害による痛みや, NSAIDS 使用の影響も考え られるが, 我々の研究では関連性が認められなかっ 
Descriptive statistics by type of hypertension.

\begin{tabular}{|c|c|c|c|c|c|c|c|c|c|}
\hline & \multicolumn{2}{|c|}{ Total } & \multicolumn{2}{|c|}{ Hypertension FH+ } & \multicolumn{2}{|c|}{ Hypertension FH- } & \multicolumn{2}{|c|}{ No hypertension } & \multirow[b]{2}{*}{$P$ value } \\
\hline & $\mathbf{n}$ & (\%) & $\mathbf{n}$ & (\%) & $\mathbf{n}$ & $(\%)$ & $\mathbf{n}$ & (\%) & \\
\hline \multicolumn{10}{|l|}{ Type } \\
\hline Hemophilia A & 419 & (87) & 100 & (85) & 63 & (84) & 256 & (88) & .54 \\
\hline Hemophilia B & 63 & (13) & 17 & (15) & 12 & (16) & 34 & (12) & \\
\hline \multicolumn{10}{|l|}{ Severity } \\
\hline Mild & 150 & (31) & 39 & (33) & 27 & (36) & 84 & (29) & .55 \\
\hline Moderate & 52 & (11) & 10 & (9) & 6 & (8) & 36 & (12) & \\
\hline Severe & 279 & (58) & 68 & (58) & 42 & (56) & 169 & (58) & \\
\hline \multicolumn{10}{|l|}{ Measures } \\
\hline Age, mean (IQR) & 55 & $(45-62)$ & 59 & $(51-68)$ & 62 & $(52-71)$ & 51 & $(43-56)$ & $<.001^{*}, \dagger$ \\
\hline BMI, mean (IQR) & 25.7 & (23.2-27.5) & 27.4 & $(24.1-29.4)$ & 26.3 & $(23.9-27.7)$ & 24.8 & (23.0-26.6) & $<.001,{ }^{*} .01^{\dagger}$ \\
\hline EGFR, mean (IQR) & 94 & $(85-107)$ & 88 & $(74-103)$ & 84 & $(69-98)$ & 100 & $(91-109)$ & $<.001^{*}, \dagger$ \\
\hline \multicolumn{10}{|l|}{ Treatment } \\
\hline On demand & 294 & (61) & 67 & (57) & 53 & (71) & 174 & $(60)$ & .37 \\
\hline No treatment & 1 & $(0)$ & 0 & $(0)$ & 0 & $(0)$ & 1 & $(0)$ & \\
\hline Prophylaxis & 171 & (35) & 48 & (41) & 19 & (25) & 104 & (36) & \\
\hline \multicolumn{10}{|l|}{ Smoker } \\
\hline No & 239 & (50) & 56 & $(48)$ & 40 & (54) & 143 & $(50)$ & .32 \\
\hline Yes & 112 & (23) & 24 & (21) & 13 & (18) & 75 & (26) & \\
\hline Previously & 127 & (27) & 37 & (32) & 21 & (28) & 69 & (24) & \\
\hline \multicolumn{10}{|l|}{ Alcohol consumption } \\
\hline Abstinent & 185 & (39) & 42 & (37) & 31 & (42) & 112 & (40) & .47 \\
\hline Low & 214 & (46) & 53 & (46) & 28 & (38) & 133 & $(47)$ & \\
\hline High & 71 & (15) & 19 & (17) & 14 & (19) & 38 & (13) & \\
\hline \multicolumn{10}{|l|}{ Comorbidities } \\
\hline NSAIDs & 93 & (19) & 29 & (25) & 12 & (16) & 52 & (18) & .20 \\
\hline Diabetes & 45 & (9) & 24 & (21) & 12 & (16) & 9 & (3) & $<.001^{*}, \dagger$ \\
\hline History of renal disease & 27 & (6) & 11 & (9) & 11 & (15) & 5 & (2) & $.01{ }^{*}<.001^{\dagger}$ \\
\hline Macroscopic hematuria & 264 & (55) & 78 & (67) & 38 & (51) & 148 & (51) & $.03,^{*}>.99^{\dagger}$ \\
\hline$<3$ bleeds & 123 & (26) & 34 & (29) & 14 & (19) & 75 & (27) & \\
\hline 3-10 bleeds & 75 & (16) & 22 & (19) & 14 & (19) & 39 & (14) & \\
\hline
\end{tabular}

図 1 血友病患者の高血圧に関連のある因子 顕微鏡的血尿と高血圧は有意に相関あり

(Qvigstad C, et al. Medicine. 2020 99: 9 より引用)

表 2 日本人血友病患者と一般男性（国民健康栄養調査上 り引用）の有病率の比較（Nagao A, et al Haemophilia 2019, 25, 4, e223-30より作成)

\begin{tabular}{lcc}
\hline & 年齢調整オッズ比 & \multicolumn{1}{c}{$95 \%$ CI } \\
\hline 高血圧 $(140 / 90$ 以上 $)$ & 1.164 & $0.968-1.399$ \\
高血圧 $(130 / 85$ 以上 $)$ & $0.797 *$ & $0.665-0.956$ \\
\hline
\end{tabular}

*有意差あり $(\mathrm{P}<0.05)$

た. NSAIDS と高血圧の関係は H3 study でも否定さ れている、いずれにせよ，高血圧の家族歴がある症 例や，インヒビター症例では血圧を注意深くモニタ リングすべきであろう.
表 3 日本人血友病患者の高血圧に関連のある因子につい ての多変量解析 (Nagao A, et al Haemophilia 2019, 25, 4, e223-30より作成)

\begin{tabular}{lll}
\hline & オッズ比 & \multicolumn{1}{c}{$95 \% \mathrm{CI}$} \\
\hline 年齢 & $1.09^{*}$ & $1.067-1.113$ \\
$\mathrm{BMI}$ & $1.149^{*}$ & $1.087-1.216$ \\
喫煙 & 1.158 & $0.759-1.766$ \\
慢性腎臓病 & $2.573 *$ & $1.343-4.93$ \\
HIV 感染 & $1.745^{*}$ & $1.04-2.928$ \\
C 型肝炎 & 1.1 & $0.679-1.783$ \\
血友病インヒビター & $7.529 *$ & $2.295-24.697$ \\
定期補充あり & 1.080 & $0.671-1.738$ \\
血友病 B (血友病 AA に対して) & 1.047 & $0.616-1.777$ \\
中等症血友病（軽症血友病に対して） & 1.254 & $0.573-2.745$ \\
重症血友病（軽症血友病に対して） & 1.418 & $0.733-2.743$ \\
\hline *有意差あり (P<0.05) & &
\end{tabular}




\section{4. 悪性腫瘍}

薬害による HCV の影響で, 血友病には HCC が多 いという特徵はあるものの, それ以外の悪性腫瘍の 発生率は一般男性と変わらない. Biron-Andreani ら は, 1,067 人の血友病患者のうち 45 例に悪性腫瘍を 認め, $\mathrm{HCC}$ と尿生殖管腫瘍が多いと報告してい る ${ }^{19)}$. 我々の研究では, 33/711 人の血友病に様々な 悪性腫瘍を認めたが特徴的な疾患はなかった（10人 の HCC を含む)，HIV 薬害感染患者におけるリンパ 腫など, 感染者に予想される悪性腫瘍も特別多いと いうわけではなかった。

\section{5. 新規インヒビター発生}

重症血友病では凝固因子製剤の 20 実投与日を ピークにインヒビター発生リスクが低下することが 知られているが, INSIGHT study グループによると 非重症型血友病では，100実投与日を過ぎても同等 のリスクが継続すると報告している ${ }^{20)}$ ．特に小巟期 の出血が少ない非重症型血友病成人患者は, 周術期 における集中的な補充療法の後にインヒビターを発 症するリスクが高いことが知られている ${ }^{21)}$. 周術期 の凝固因子投与量を加減することはできないため, 万が一インヒビターが発生した場合の治療戦略や, その後の日常生活の変化についてもある程度事前に 説明した上で, 厳重な informed consentを術前に取得 しておく必要があると考えられる。非重症型血友病 においてインヒビターを発生しやすい遺伝子変異の ホットスポットが複数報告されており, 可能であれ ば非重症型血友病患者の遺伝解析を事前に行ってお くことも有用かもしれない.さらに周術期・術後に は，こまめに APTT, 第 VIII 因子活性, インヒビター 力価を測定し, APTT 延長の程度 (や第 VIII 因子活 性）あるいは出血症状によってインヒビター発生の 予見あるいは早期発見に務めることも重要である.

一方, Hay らは重症血友病患者においても 60 歳以 上で 2 回目のインヒビター発生のピークがある可能 性を示唆している ${ }^{22)}$. ADVANCEグループでも, NIAP study (New Inhibitors in People with Hemophilia Aged 40 Years and Older) の中で 40 歳以上の 2,562 人
の 10 年間の解析で, 1,222 人の重症血友病患者中 19 人 $(1.5 \%)$ にインヒビターが発生し, うち 7 人は定 期補充療法実施中, 5 人は周術期に発生しており, 3 人はインヒビターの既往歴があったと報告してい る ${ }^{22)}$. 本報告では, 特に 60 歳以上の重症血友病患 者でインヒビター発生が多いわけではないが, 定期 補充中の重症血友病患者に抒いても, 高齢化による 免疫機能の変化でインヒビターが発生する可能性が あることを十分に知って治療にあたるべきであろう。

\section{6. 筋骨格系}

\section{1）整形外科的手術と予防的抗凝固薬}

成人血友病患者は定期補充療法以前の治療により 既に血友病性関節症が進行している例が多く, 整形 外科的手術，とくに人工関節置換術を受ける患者も 多い. 我々の調査では 40 代で $8 \%, 50$ 代で $16 \%, 60$ 代以上で $15 \%$ が整形外科的手術の既往があった. 周 術期管理で問題となるのが静脈血栓症（venous thromboembolism: VTE）の予防であるが，日本整形 外科学会症候性静脈塞栓症予防ガイドライン 2017 によると, VTEリスクが高い整形外科手術は人工股 関節全置換術 (total hip arthroplasty: THA), 人口膝関 節全置換術（total knee arthroplasty: TKA），股関節骨 折手術であり, 低分子量へパリンかエドキサバンな どの投与が GradeB で推奨されている。これらの手 術は血友病患者においてよく行われるが, DVTの予 防的抗凝固薬の使用についてのコンセンサスは得ら れていない. 米国で行われた多施設共同前向き試験 によると, 血友病患者で 46 の THA と TKAが行われ たうち, 予防的抗凝固薬が使用されたのは 4 例であっ た。この試験では抗凝固非実施例 2 人にVTEが発 生し ${ }^{23)}$ た，我が国では大野らが11 人の TKAについ てまとめており，いずれも予防的抗凝固薬は使用さ れていない. 11 例中造影 CT で検出された VTEが 2 例あったが, 症候性の VTEではなく, VTE 非発症例 と比較して有意な特徴はなかった ${ }^{24)}$. 日本整形外科 学会は2017年まで「無症候性VTEを含むすべての VTE」を予防対象としていたが，2017年に「症候性 VTE」を対象に予防ガイドラインを発刊した。 患者 にとって重要なことは無症候性のVTEの減少ではな 
く, 症候性 VTE, 致死性肺血栓塞栓症と出血合併症 であるという国際ガイドラインの動向に沿ったもの であり，血友病においてもまずは止血管理を厳重に 行うことが重要で, 予防的抗凝固薬の使用について は，今のところ必須とするエビデンスはない. 残念 ながら, VTEを起こしてしまった場合の治療につい ても，今のところ推奨できるエビデンスはない.

\section{2) 骨密度低下}

血友病患者では，出血あるいは関節症のため積極 的な運動が困難であったことから，骨密度が低い可 能性が示唆されてきた. Kemptonらは, 50 歳以上 26 人の血友病患者において, 重症度に関係なく骨粗鬆 症が $38 \%$, 骨質減少 $42 \%$ が認められ（重症 $44 \%$, 中等症 25\%, 軽症 39\%), 米国の一般男性における 骨粗鬆症の有病率 5.7\%（65 歳以上）よりも有意に 高いと報告した ${ }^{25)}$. Kiper らも50 歳以上の $67 \%$ に骨 粗鬆症があったとしている ${ }^{26)}$ 。我々の調査では, 50 歳以上の血友病患者における骨粗鬆症薬の処方率は 263 人中 8 人 $(3 \%)$ のみであったが, これは日本人 血友病患者の骨密度が保たれていることを示すもの ではなく, 骨密度検査が行われていない結果かもし れない，骨密度低下で問題となるのは身体能力の劣 弱化と大腿骨頸部骨折のリスク増大であるが，46歳 以上の血友病患者では一般集団と比較して骨折歴を 有する患者が有意に多いとする報告もある ${ }^{27)}$ 。これ まで血友病の骨密度低下や骨折のリスク因子には, 一般的なリスク (喫煙, 飲酒, 家族歴, 生活習慣病 など）に加え, 血友病性関節症, 慢性滑膜炎 (炎症), HIV 感染症, HCV 感染症などが考えられてきた. 最 近, 凝固第 VIII/IX 因子欠乏自体が骨質に影響するの ではないかという報告が相次いでいるが，未だ結論 は出ていない ${ }^{14)}$. 少なくとも, 一般的に男性におい てリスクが高いと言われる年齢である 50 歳以上の血 友病患者や HIV を合併する患者においては定期的な 骨密度測定をすべきであると考えられる，骨密度低 下の予防としては, 一般的な生活習慣の是正や適度 な運動, 適度な運動が難しい患者では理学療法を積 極的に推奨すべきである. 英国の血友病専門家団体 $\mathrm{UKHCDO}$ も早期の理学療法導入を推奨している ${ }^{28)}$.

\section{7. まとめ}

成人血友病患者の診療において今後問題になる可 能性が高い疾患についてまとめた。 今後, ガイドラ イン作成が望まれる分野であり，ヨーロッパと我々 が進めている前向き試験の結果がそれに寄与するこ とを期待している.

著者の利益相反 (COI) の開示 :

講演料・原稿料など (Sanofi, Takeda), 臨床研究 (治 験）（サノフィ株式会社, ファイザー株式会社, ノボ ノルディスクファーマ株式会社, 中外製薬株式会社, バイエル薬品株式会社, Octapharma $\mathrm{AG}$ ), 研究費 (受託研究，共同研究，寄付金等）（Takeda, Bayer）

\section{文献}

1) AIDS JF for. Project entrusted by Ministry of Health, Labour And Welfare. Nationwide Survey on Coagulation Disorders 2019.

2) Manco-Johnson MJ, Kempton CL, Reding MT, Lissitchkov T, Goranov S, Gercheva L, Rusen L, Ghinea M, Uscatescu V, Rescia V HW: Randomized, controlled, parallel-group trial of routine prophylaxis vs. on-demand treatment with sucroseformulated recombinant factor VIII in adults with severe hemophilia A (SPINART). J Thromb Haemost 11: 1119-1127, 2013.

3) Hartmann J: 2017 Clinical trials update: Innovations in hemophilia therapy. Am J Hematol 91: 1252-1260, 2016.

4) Nagao A, Hanabusa $H$ : The impact of ledipasvir/sofosbuvir on HIV-positive and HIV-negative Japanese hemophilia patients with 1, 4, and mixed-genotype $\mathrm{HCV}$. J Acquir Immune Defic Syndr 74: 418-422, 2017.

5) ADVANCE. p. https://advance-haemophilia.eu/.

6) Nagao A: ADVANCE in Japan.

7) Nagao A, Suzuki N, Takedani H, Yamasaki N, Chikasawa Y, Sawada A, Kanematsu T, Nojima M, Higasa S, Amano K, Fukutake K, Fujii T, Matsushita T, Suzuki T: Ischaemic events are rare, and the prevalence of hypertension is not high in Japanese adults with haemophilia: First multicentre study in Asia. Haemophilia 25: e223-e230, 2019.

8) Fransen van de Putte DE, Fischer K, Makris M, Tait RC, Chowdary P, Collins PW, Meijer K, Roosendaal G, Schutgens REG, Mauser-Bunschoten EP: History of non-fatal cardiovascular disease in a cohort of Dutch and British patients with haemophilia. Eur J Haematol 89: 336-339, 2012.

9) Minuk L, Jackson S, Iorio A, Poon M-C, Dilworth E, Brose K, Card R, Rizwan I, Chin-Yee B, Louzada M: Cardiovascular disease (CVD) in canadians with haemophilia: Age-related CVD in haemophilia epidemiological research (ARCHER study). Haemophilia 21: 736-741, 2015.

10) Wang J-D, Chan W-C, Fu Y-C, Tong K-M, Chang S-T, 
Hwang W-L, Lin C-H, Tsan Y-T: Prevalence and risk factors of atherothrombotic events among 1054 hemophilia patients: a population-based analysis. Thromb Res 135: 502-507, 2015.

11) Makris M, Van Veen JJ: Reduced cardiovascular mortality in hemophilia despite normal atherosclerotic load. J Thromb Haemost 10: 20-22, 2012.

12) Posma JJ, Grover SP, Hisada Y, Owens AP, Antoniak S, Spronk HM, Mackman N: Roles of coagulation proteases and PARs (protease-activated receptors) in mouse models of inflammatory diseases. Arterioscler Thromb Vasc Biol 39: 13-24, 2019.

13) Boehnel C, Rickli H, Graf L, Maeder MT: Coronary angiography with or without percutaneous coronary intervention in patients with hemophilia-Systematic review. Catheter Cardiovasc Interv 92: 1-15, 2018.

14) Kempton CL, Makris M, Holme PA: Management of comorbidities in haemophilia. Haemophilia 2020.

15) Staritz P, de Moerloose P, Schutgens R, Dolan G: Applicability of the European Society of Cardiology guidelines on management of acute coronary syndromes to people with haemophilia — an assessment by the ADVANCE Working Group. Haemophilia 19: 833-840, 2013.

16) Qvigstad C, Tait RC, de Moerloose P, Holme PA: Hematuria in aging men with hemophilia: Association with factor prophylaxis. Res Pract Thromb Haemost 4: 309-317, 2020.

17) Holme PA, Combescure C, Tait RC, Berntorp E, Rauchensteiner S, de Moerloose P: Hypertension, haematuria and renal functioning in haemophilia - a cross-sectional study in Europe. Haemophilia 22: 248-255, 2016.

18) Miesbach W, Reitter-Pfoertner S-E, Klamroth R, Langer F, Wolf HH, Tiede A, Siegmund B, Scholz U, Müller PR, Eichler H, Pabinger I: Co-morbidities and bleeding in elderly patients with haemophilia-A survey of the German, Austrian and Swiss Society of Thrombosis and Haemostasis Research (GTH). Haemophilia 23: 721-727, 2017.

19) Biron-Andreani C, de Moerloose $P$, D'oiron R, Chambost H, Schved JF, Hermans C: Cancer detection and management in patients with haemophilia: A retrospective European multicentre study. Haemophilia 20: 78-82, 2013.

20) Eckhardt CL, Van Velzen AS, Peters M, Astermark J, Brons PP, Castaman G, Cnossen MH, Dors N, EscuriolaEttingshausen C, Hamulyak K, Hart DP, Hay CRM, Haya S, Van Heerde WL, Hermans C, Holmström M, Jimenez-Yuste $\mathrm{V}$, Keenan RD, Klamroth R, Laros-van Gorkom BAP, Leebeek FWG, Liesner R, Mäkipernaa A, Male C, MauserBunschoten E, Mazzucconi MG, McRae S, Meijer K, Mitchell M, Morfini M, Nijziel M, Oldenburg J, Peerlinck K, Petrini P, Platokouki H, Reitter-Pfoertner SE, Santagostino E, Schinco P, Smiers FJ, Siegmund B, Tagliaferri A, Yee TT, Kamphuisen PW, van der Bom JG, Fijnvandraat K, INSIGHT Study Group: Factor VIII gene (F8) mutation and risk of inhibitor development in nonsevere hemophilia a. Blood 122: 1954-
1962, 2013.

21) van Velzen AS, Eckhardt CL, Peters M, Leebeek FWG, Escuriola-Ettingshausen C, Hermans C, Keenan R, Astermark J, Male C, Peerlinck K, le Cessie S, van der Bom JG, Fijnvandraat K: Intensity of factor VIII treatment and the development of inhibitors in non-severe hemophilia A patients: results of the INSIGHT case-control study. J Thromb Haemost 15: 1422-1429, 2017.

22) Hay CRM, Palmer B, Chalmers E, Liesner R, MacLean R, Rangarajan S, Williams M, Collins PW: Incidence of factor VIII inhibitors throughout life in severe hemophilia $\mathrm{A}$ in the United Kingdom. Blood 117: 6367-6370, 2011.

23) Buckner TW, Leavitt AD, Ragni M, Kempton CL, Eyster ME, Cuker A, Lentz SR, Ducore J, Leissinger C, Wang M, Key NS: Prospective, multicenter study of postoperative deep-vein thrombosis in patients with haemophilia undergoing major orthopaedic surgery. Thromb Haemost 116: 42-49, 2016.

24) Ono K, Takedani H: Risk of deep venous thrombosis after total knee arthroplasty in patients with haemophilia A. Haemophilia 2020.

25) Kempton CL, Antun A, Antoniucci DM, Carpenter W, Ribeiro M, Stein S, Slovensky L, Elon L: Bone density in haemophilia: A single institutional cross-sectional study. Bone 20: 1-7, 2014.

26) Kiper Unal HD, Comert Ozkan M, Atilla FD, Demirci Z, Soyer N, Yildirim Simsir I, Omur O, Capaci K, Saydam G, Sahin F: Evaluation of bone mineral density and related parameters in patients with haemophilia: a single center crosssectional study. Am J Blood Res 7: 59-66, 2017.

27) Gay ND, Lee SC, Liel MS, Sochacki P, Recht M, Taylor JA: Increased fracture rates in people with haemophilia: A 10-year single institution retrospective analysis. $\mathrm{Br} \mathrm{J}$ Haematol 170: 584-586, 2015.

28) Hanley J, Mckernan A, Creagh MD, Classey S, Mclaughlin P, Goddard N, Briggs PJ, Frostick S, Giangrande P, Wilde J, Thachil J, Chowdary P, ON BEHALF OF THE MUSCULOSKELETAL WORKING PARTY OF THE UKHCDO: Guidelines for the management of acute joint bleeds and chronic synovitis in haemophilia A United Kingdom Haemophilia Centre Doctors, Organisation (UKHCDO) guideline. Haemophilia 1-10, 2017.

29) Lövdahl S, Henriksson KM, Baghaei F, Holmström M, Berntorp E, Astermark J: Hypertension and cardiovascular diseases in Swedish persons with haemophilia - A longitudinal registry study. Thromb Res 181: 106-111, 2019.

30) Sood SL, Cheng D, Ragni M, Kessler CM, Quon D, Shapiro $\mathrm{AD}$, Key NS, Manco-Johnson MJ, Cuker A, Kempton C, Wang TF, Eyster ME, Kuriakose P, von Drygalski A, Gill JC, Wheeler A, Kouides P, Escobar MA, Leissinger C, Galdzicka $\mathrm{S}$, Corson M, Watson C, Konkle BA: A cross-sectional analysis of cardiovascular disease in the hemophilia population. Blood Adv 2: 1325-1333, 2018. 